\title{
Zoonotic Importance of Some Pathogenic Bacteria Isolated from Small Ruminants' Milk and Hands of Dairy Workers
}

\author{
Heba S. El-Mahallawy ${ }^{1 *}$, Mahmoud Elhariri², Rehab Elhelw ${ }^{2}$ and Dalia Hamza ${ }^{3}$ \\ ${ }^{1}$ Animal Hygiene, Zoonoses and Animal Behaviour and Management Department, Faculty of \\ Veterinary Medicine, Suez Canal University, Ismailia, 41522, Egypt \\ ${ }^{2}$ Microbiology Department, Faculty of Veterinary Medicine, Cairo University, Cairo, Egypt \\ ${ }^{3}$ Zoonoses Department, Faculty of Veterinary Medicine, Cairo University, Cairo, Egypt \\ Article History: Received: 17/7/2017 Received in revised form: 24/10/2017 Accepted: 1/11/2017
}

\begin{abstract}
Staphylococcus aureus and enteropathogenic Escherichia coli are among zoonotic bacterial food-borne pathogens causing illness ranged from diarrhoea to fatal conditions. This study was undertaken to evaluate the occurrence of Staph. aureus and E. coli in small ruminants' raw milk and hands of dairy workers at small-scale production units, Giza, Egypt. A total of 420 raw milk samples were obtained from apparently healthy sheep and goats, also, hand swabs $(n=46)$ from workers at the units under investigation were examined. Overall, Staph. aureus $(13.1 \%, 55 / 420)$ and $E$. coli $(26.2 \%, 110 / 420)$ isolates were obtained from raw milk of sheep and goats. However, only Staph. aureus $(15.2 \%, 7 / 46)$ was recovered from hand swabs of dairy workers. Using PCR, all the tested Staph. aureus isolates from milk and hand swabs yielded specific bands of Thermonuclease (nuc) gene at $279 \mathrm{bp}$, however, amplification of virulence (eae) gene encoding the intimin protein of $E$. coli produced an amplicon of $917 \mathrm{bp}$ in $45 \%$ of the tested $E$. coli isolates. In conclusion, our findings provide an overview about Staph. aureus and E. coli contamination in raw milk of small ruminants locally bred by smallholders and suggest probably transmission of Staph. aureus from hands of dairy workers that contaminate the milk or udder of apparently healthy animals. Reporting of such organisms from milk indicates the need for strict hygienic measures during milking at these production units.
\end{abstract}

Keywords: Raw milk, Dairy workers, Sheep, Goat, E. coli, Staph. aureus.

\section{Introduction}

Milk is a highly nutritious food for human beings from childhood to senility. It also serves as a good medium for the growth of many microorganisms especially bacterial pathogens particularly in tropical areas. Lactobacillus, Streptococcus, Staphylococcus, Escherichia coli and Micrococcus spp. are among the commonly detected bacteria in fresh milk [1].

Sheep and goats are considered the second most important milk producers after dairy cattle and buffaloes, in both temperate and tropical agriculture [2]. In Mediterranean countries, milk from small ruminants has always been a part of people's traditional food [3]. The need for milk from sheep is increasingly rising, moreover, dairy goat industry currently gaining more attention worldwide [4].
There have been few attempts to determine the microbial loads in small ruminants' raw milk in Egypt, since most of dairy industry mainly rely on milk from cattle and. Although the burden of various etiological agents in milk-borne diseases has dramatically changed over time, more than $90 \%$ of all reported cases of dairy-related illnesses continue to be of bacterial origin [5].

Presence of microorganisms in milk and milk products greatly affect its quality and safety, furthermore, it has a considerable public health implications. Staphylococci are frequently recovered from raw milk of animals. Staphylococcus aureus has been reported as an important etiological agent of subclinical and clinical mastitis [6]. Moreover, this organism usually present among the normal flora in the anterior nares and skin of humans and animals [7], and interchange of

*Corresponding author email: (dr_ba1012_2@ @otmail.com), Animal Hygiene, Zoonoses and Animal 305 Behaviour and Management Department, Faculty of Veterinary Medicine, Suez Canal University, Ismailia, 41522, Egypt. 
Staph. aureus between humans and animals due to close contact has been previously reported [8-10], posing a zoonotic risk and notable threats regarding food hygiene. The presence of high numbers of these bacteria in milk increases the risk of staphylococcal toxin production which is highly resistant to heat treatment by pasteurization [11].

$E$. coli is recognized as a serious foodborne pathogen and has been associated with numerous disease outbreaks worldwide [12]. Raw milk and dairy products such as pasteurized milk and yoghurt contaminated with $E$. coli have been reported as the main cause of several food borne disease outbreaks since the 1980s and thus constitutes a serious health threat $[13,14]$.

In Egypt, large number of sheep and goats are bred in small groups (usually 20-30 animals/herd) by smallholders in peri-urban areas where they share in pasture and shelter. On contrary to machine milking in large ruminants' dairy farms, small ruminants in local small-scale units are managed and milked by hands of their smallholders, thus increasing the probable risk of milk contamination or disease transmission. This study aimed to determine the frequency of two of the most important zoonotic bacterial pathogens, Staph aureus and E. coli, in small ruminants' raw milk and hands of their dairymen at small-scale production units in Giza, Egypt to evaluate the level of sanitary measures fulfilled by dairy workers during milking process.

\section{Materials and Methods}

\section{Sample collection}

\section{Milk samples}

A total of 420 raw milk samples (220 sheep and 200 goats) were collected from small locally bred herds in Giza, Egypt. Teats of the udder were disinfected with $70 \%$ ethyl alcohol and left to dry. First milk strips were discarded and $10 \mathrm{~mL}$ of milk from each animal was collected by its owner in sterile labelled capped cups then placed directly in an ice box.

\section{Hand swabs from dairy workers}

Pre-moistened saline swabs were rolled on the palm of hands and fingers of forty-six dairy workers prior to milking in the visited units. Swabs were aseptically placed back in their labelled tubes. Following collection, all milk samples and swabs were shipped on ice within $2 \mathrm{~h}$ of collection to the Microbiology Department's Laboratory, Faculty of Veterinary Medicine, Cairo University. Informed verbal/written consent for participation was obtained from all the participants.

\section{Isolation and identification of Staph. aureus}

One millilitre from each well mixed sample was aseptically enriched into Brain heart infusion broth tubes (Oxoid, Hampshire, UK) and incubated at $37^{\circ} \mathrm{C}$ for $24 \mathrm{~h}$. Two loopfuls from each enrichment broth was streaked onto mannitol salt agar plates (Oxoid, Hampshire, UK) and incubated at $37^{\circ} \mathrm{C}$ for $24 \mathrm{~h}$. Positive Staph. aureus colonies were identified by mannitol fermentation with yellow colour production. Each suspected isolate was tested for its haemolytic activity by streaking on $5 \%$ defibrinated sheep blood agar (Oxoid Ltd, Hampshire, UK) incubated at $37^{\circ} \mathrm{C}$ for $24 \mathrm{~h}$. Typical colonies were further identified by Gram-stained smears and examined for their catalase activity as described previously [15]. Production of coagulase by Staph. aureus strains was also determined using rabbit plasma. Briefly, $0.2 \mathrm{~mL}$ of overnight grown tested broth was added to tubes containing 1 $\mathrm{mL}$ of 1:10 diluted rabbit plasma. Stable gelling of plasma was observed during incubation at $37^{\circ} \mathrm{C}$ with half hour intervals for 4 hours.

\section{Isolation and identification of Enterobacteriaceae}

One millilitre from each well mixed sample was inoculated into buffered peptone water at $37^{\circ} \mathrm{C}$ for $24 \mathrm{~h}$. Two loopfuls from each enrichment broth were streaked on each MacConkey and Eosin methylene blue (EMB) (Oxoid, Ltd, Hampshire, UK) agar plates and incubated at $37^{\circ} \mathrm{C}$ for $24 \mathrm{~h}$. Morphologically typical E. coli colonies with green metallic sheen on EMB were transferred into nutrient agar plates and broth for further morphological identification and Gram staining as described previously $[16,17]$ and biochemical identification using RapID ONE test (Oxoid, remel, USA) was carried out. 
Table 1: Primer sequences of nuc gene specific for Staph. aureus and eae gene specific for EPEC E. coli

\begin{tabular}{lcc} 
Target gene & Oligonucleotide sequence & $\begin{array}{c}\text { Size of amplified } \\
\text { product }\end{array}$ \\
\hline $\boldsymbol{n} \boldsymbol{u} \boldsymbol{c}^{1}$ & 5'-GCGATTGATGGTGATACGGTT-3' & $279 \mathrm{bp}$ \\
$\boldsymbol{e a}^{2}$ & 5'-AGCCAAGCCTTGACGAACTAAAGC-3' & \\
& 5-CTGAACGGCGATTACGCGAA-3 & 5-CCAGACGATACGATCCAG -3 \\
\hline
\end{tabular}

${ }^{1}$ The $n u c$ primer pair were used for identification of Staph. aureus,

${ }^{2}$ primer pair specific for eae gene encoding intimin for identification of EPEC E. coli.

\section{Polymerase chain reaction}

Genomic DNA was extracted from crude cell lysate of bacterial isolates using rapid boiling procedures [18]. Briefly, two to five bacterial colonies were randomly picked up from fresh grown positive cultures and were then suspended in $200 \mu \mathrm{L}$ DNA-RNA free water. After boiling for $10 \mathrm{~min}$ in water bath, the supernatant was separated following centrifugation at $10.000 \mathrm{rpm}$ for $5 \mathrm{~min}$. The extracted DNA template was kept at $-20^{\circ} \mathrm{C}$ until being used in PCR assay.

Amplification of specific Staph. aureus nuc gene [19] and specific eae E. coli gene encoding intimin sequence [20] was performed as previously described. All oligonucleotide primers were purchased from Sigma Genosys (Sigma) and their sequences are listed in Table 1.

The reaction mixture consisted of $12.5 \mu \mathrm{L}$ $1 \times$ of PCR master mix (Dream Taq Green PCR Master Mix, Fermentas Life Science), 3 $\mu \mathrm{L}$ bacterial DNA template, $0.5 \mu \mathrm{L}$ of each primer with concentration of $50 \mathrm{pmol}$ and nuclease free water up to $25 \mu \mathrm{L}$. The reaction was run in PCR thermal cycler (Swift MiniPro, ESCO. Philadelphia, USA). Positive control was kindly provided from Zoonoses Department, Faculty of Veterinary Medicine, Cairo University, Egypt was involved in each PCR run. DNase RNase free water was used as negative control. The cycling conditions for Staph. aureus nuc gene involved initial denaturation at $98^{\circ} \mathrm{C}$ for 5 min followed by 37 PCR cycles under the following conditions: denaturation at $94^{\circ} \mathrm{C}$ for $1 \mathrm{~min}$, primer annealing at $53^{\circ} \mathrm{C}$ for $0.5 \mathrm{~min}$, and DNA extension at $72^{\circ} \mathrm{C}$ for $1.5 \mathrm{~min}$ and the reaction was terminated by a final extension at $72^{\circ} \mathrm{C}$ for $3.5 \mathrm{~min}$. For $E$. coli specific eae gene, the cycling conditions involved $95^{\circ} \mathrm{C}$ for $5 \mathrm{~min}$ followed by 40 cycles of $95^{\circ} \mathrm{C}$ for $45 \mathrm{sec}$, $50^{\circ} \mathrm{C}$ for $1 \mathrm{~min}, 72^{\circ} \mathrm{C}$ for $1 \mathrm{~min}$ and final extension at $72^{\circ} \mathrm{C}$ for $7 \mathrm{~min}$. Amplified products $(10 \mu \mathrm{L})$ were then visualized under UV light and photographed after being electrophoresed on $1.5 \%$ agarose gel stained with ethidium bromide and 0.5X TBE buffer for $45 \mathrm{~min}$.

\section{Results}

In this study, the frequency of bacterial isolation from raw milk and hand swabs of dairy workers is shown in Table 2. Colony characteristics, gram stain and biochemical identification, conventionally confirmed that the isolates were classified as Staph. aureus or as E. coli. The frequency of Staph. aureus isolated from raw milk and dairy workers' hand swabs was $13.1 \%(55 / 420)$ and $15.2 \%$ (7/46), respectively. However, no E. coli isolates were obtained from dairy workers' hand swabs (Table 2). Notably, sheep milk $(14.1 \%$ and $29 \%)$ showed higher rate of contamination with Staph. aureus and E. coli than goats' milk (12\% and 23\%), respectively. 
Table 2: Total Staph. aureus and $E$. coli isolates obtained from raw milk of sheep and goats and hand swabs of dairy workers.

\begin{tabular}{lccccc}
\hline \multirow{2}{*}{ Source of sample } & \multirow{2}{*}{$\begin{array}{c}\text { Total No. } \\
\text { examined }\end{array}$} & \multicolumn{2}{c}{ Staph. aureus } & \multicolumn{2}{c}{ E. coli } \\
\cline { 3 - 6 } & & $+\mathrm{+ve}$ & $\boldsymbol{\%}$ & $+\mathrm{ve}$ & $\boldsymbol{\%}$ \\
\hline Sheep milk & 220 & 31 & 14.1 & 64 & 29 \\
Goat milk & 200 & 24 & 12 & 46 & 23 \\
Dairymen hand swabs & 46 & 7 & 15.2 & -- & -- \\
\hline
\end{tabular}

Molecular identification of randomly selected Staph. aureus isolates obtained from 10 sheep milk, 10 goats' milk and 7 human hand swabs, revealed the amplification of specific band of Thermonuclease nuc gene at 279 bp (Figure 1). However, specific eae gene encoding intimin of $E$. coli was detected in $40 \%$ (4 out of 10) and $50 \%$ (5 out of 10) of randomly selected $E$. coli isolates from raw milk of sheep and goats, respectively (Figure 2).

\section{Discussion}

This study provides an overview about the frequency of two zoonotic bacterial pathogens that may be present in sheep and goat's raw milk and the probable risk of their transmission from their dairy workers at small- scale bred herds in Giza, Egypt. In this study, overall, Staph. aureus $(13.1 \%, 55 / 420)$ and $E$. coli $(26.2 \%, 110 / 420)$ were isolated from raw milk of small ruminants. This was lower than previous reports of Staph. aureus of milk from several ruminant species $56 \%$ [21], 40\% [22], and $40 \%$ [23]; however, our findings were higher than $7.3 \%$ [24] and 6.6\% [25] reported in other studies. Although these variable prevalence rates mentioned in the literature vary in different geographical regions and with variable sample sizes; contamination and spoilage of sheep and goats' milk with these pathogens can generally be encountered due to poor hygienic conditions and management maintained at these small local backyards during milking or due to improper handling, inadequate storage and transport [26].

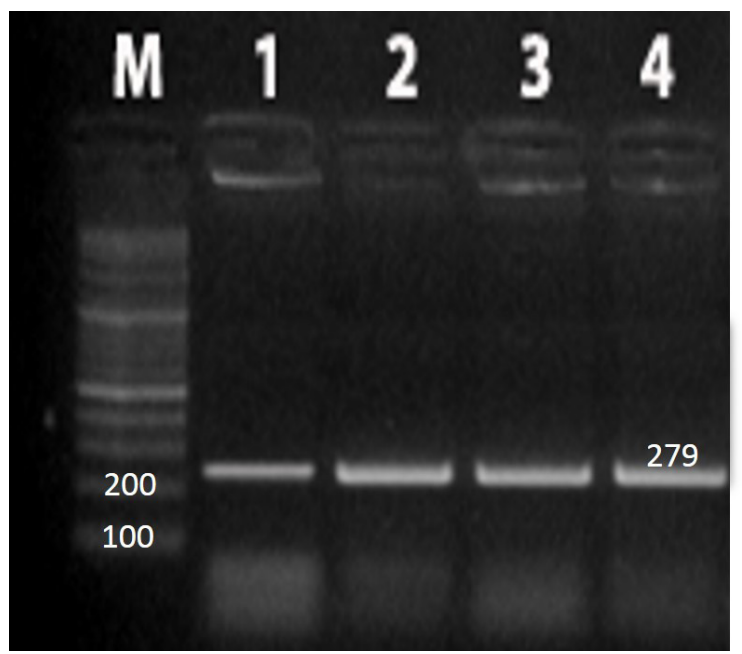

Figure 1: Typical amplification of the specific 279 bp fragment of nuc gene from some Staph. aureus isolates. Lane Marker: molecular DNA ladder, Lanes 1,2: Staph. aureus isolates from sheep milk, Lane 3: Staph. aureus isolate from goat milk, Lane 4: Staph. aureus isolate from dairy workers' hand swabs. 
Raw milk might get contaminated by Staph. aureus from infected mammary glands of the animals [27]. Also, Staph. aureus is a wellknown flora of the anterior nares and skin of human beings [28]. Detection of a high rate $(15.2 \%, 7 / 46)$ of Staph. aureus isolates from dairy workers' hand swabs in our study, might suggest the probable risk of Staph. aureus direct transmission through their contaminated hands to the animals' mammary glands or the milk itself [29]. Referring to our observations in the visited farms and during sample collection, dairy workers were applying hand milking and unhygienic practices in the milking process. In other studies, from Egypt, lower isolation rate of Staph. aureus from dairy workers' hands was reported in Sharkia Governorate (10\%) [30]; however, Staph. aureus was isolated at higher rates from dairy workers in Ismailia (60\%) [31] and Aswan (44.1\%) [32].

On the other hand, although the sampled animals were clinically normal at the time of sample collection, we believe that subclinical mastitis may also share with a considerable percentage in the Staph. aureus positivity of milk. In this regard, reports stated that Staph. aureus represented $37 \%$ of the isolates causing subclinical mastitis in goats [33]. Previously reported outbreak of foodborne illness associated with consumption of raw goats' milk has been attributed to its increased favourable nutrient contents, which in turn encourages the growth and proliferation of microorganisms [9].

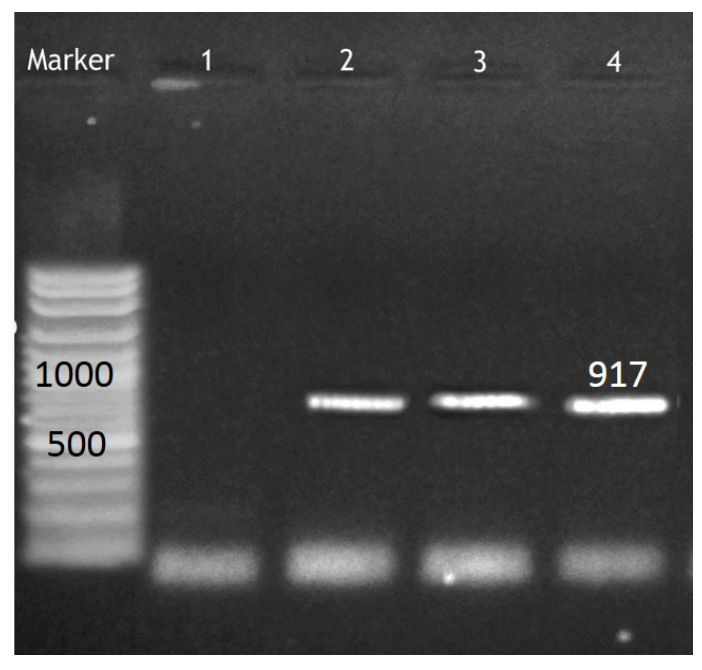

Figure 2: Typical amplification of the specific $917 \mathrm{bp}$ fragment of eae gene from some $E$. coli isolates. Lane Marker: molecular DNA ladder, Lane 1: negative sample, Lanes 2,3: $E$. coli isolates from sheep milk, Lane 4: E. coli isolate from goat milk.

The microbial load of the examined milk samples revealed higher frequency of $E$. coli $(26.2 \%, 110 / 420)$ than $(13.1 \%, 55 / 420)$ Staph. aureus (Table 2). Ruminants are usually identified as one of the important reservoirs for EPEC/STEC (also called verotoxinproducing E. coli). In Egypt, cattle, goats and sheep are considered a potential source of $E$. coli infection to humans, with the important serotypes are O26, O86, O111, O126, O127, O157, O158 and O164 [34]. They shed the bacteria into the environment throughout their faeces without even suffering from clinical disease, thus allowing meat and milk contamination causing human foodborne illness following consumption of such food [35]. In this regard, Food Regulations Act stated that coliform count shouldn't exceed 1.7 $\log \mathrm{CFU} / \mathrm{mL}$ and $E$. coli shouldn't be present in even one $\mathrm{mL}$ of a milk sample [29]. Therefore, high detection rate of $E$. coli from milk in this study is an evidence for faecal 
contamination. Furthermore, other contributing factors such as poor hygiene and sanitary practice at the farm could also play a significant role. Since dairy farms have complex surroundings, coliforms present in the faeces, manure and soil, might be easily dispersed throughout the farm [29,36]. In other studies, E. coli was isolated from milk at higher rate $(76.4 \%)$ from Egypt [37] and $33.9 \%$ from Western Ethiopia [38]. Notably, sheep milk showed high bacterial contamination with both pathogens than goats' milk. This may be due to the nature of each animal species coat, where heavy wool of sheep may help in carrying more contaminants from the environment that contaminate the milk during milking.

In this study, PCR was used for molecular characterization of the bacteriologically suspected Staph. aureus and E. coli isolates. Amplification revealed specific 279 bp fragment of Staph. aureus thermonuclease nuc gene from all the tested 27 isolates (10 from sheep, 10 from goats and 7 from hand swabs). Similar results to our findings were previously reported $[23,39,40]$.

Specific 917 bp fragment of E. coli eae intimin gene have been detected in 9 of the 20 testes E. coli isolates obtained from milk samples (10 from sheep and 10 from goats). The detection of intimin gene in the tested $E$. coli isolates is of special concern regarding food safety and human health since its detection is linked to the presence of enteropathogenic Escherichia coli (EPEC) [41], the strains which have been identified as one of the major foodborne pathogens in humans. However, lower percentages of $E$. coli isolates carrying intimin gene by PCR were previously reported $(65.9 \%)$ [42] and (21\%) [43].

\section{Conclusion}

This study provides an evidence of Staph. aureus and E. coli as hazardous in raw milk from apparently healthy sheep and goat and the probable risk of Staph. aureus transinfection from their milk handlers in Giza, Egypt. Improvement of hygienic and management practices at small backyards will reduce milk contamination with these pathogens and consequently their transmission to humans. More effort is needed to increase the awareness of smallholders about the importance of obtaining a safe good quality milk at their production and sale units. Ultimately, milk testing programs should be a component in small-scale production units to production of high quality milk.

\section{Conflict of interest}

Authors declare that they don't have any conflict of interest.

\section{Acknowledgment}

The authors would like to thank the dairymen for their cooperation and help in giving swab samples from their hands and milk form their animals.

\section{References}

[1] Chye, F.K.; Abdullah, A. and Ayob, M. K. (2004): Bacteriological quality and safety of raw milk in Malaysia. Food Microbiol, 21(5): 535- 541.

[2] Farnworth, E. (2002): Goat Milk - A dairy products with Special Properties? June 2002 No.14810.5455/vetworld.2012.103109

[3] Mens, P.L. (1985): Properties physicochimiques nutritionnelles etchimiques (physico-chemical properties). In: Luquet (ed) lait etproduits laitiéres deVaches,Brebis et chévre (Milk and Milk products from cows, sheep and goats). Apria, Paris, pp. 349-367

[4] Boscos, C.; Stefanakis, A.; Alexopoulos, C. and Samartzi, F. (1996): Prevalence of subclinical mastitis and influence of breed, parity stage of lactation and mammary bacteriological status on coulter counts and California mastitis test in milk of Saanen and autochthonous goats. Small Rumini Res, 21(2): 139-147.

[5] Bean, N.H.; Goulding, J. S.; Lao, C. and Angulo, F. J. (1996): Surveillance of foodborne disease outbreaks-United States, 1988-1992. Morbidity and Mortality Weekly Report CDC Surveillance Summaries, 45(SS-5): 1-555.

[6] Le Loir, Y.; Baron, F. and Gautier, M. (2003): Staphylococcus aureus and food poisoning. Genet Mol Res, 2(1): 63-76. 
[7] Rosdahl, V.T.; Gahrn-Hansen, B.; Moller, J. K. and Kjaeldgard, P. (1990): Phagetyping of coagulase-negative staphylococci. Factors influencing typability. APMIS, 98: 299-304.

[8] Wolfe, N.D.; Daszak, P.; Kilpatrick, A. M. and Burke, D. S. (2005): Bushmeat hunting, deforestation, and prediction of zoonotic disease emergence. Emerging Infect Dis, 11(12): 1822-1827.

[9] Seifu, E.; Buys, E.M.; Donkin, E. F. and Petzer, I.M. (2004): Antibacterial activity of the lactoperoxidase system against foodborne pathogens in Saanen and South African indigenous goat milk. Food Control, 15(6): 447-452.

[10] Jones, K. E.; Patel, N. G.; Levy, M. A.; Storeygard, A.; Balk, D.; Gittleman, J. L. and Daszak, P. (2008): Global trends in emerging infectious diseases. Nature, 451(7181): 990-993.

[11] Tortora, G.J.; Funke, B.R. and Case, C.L. (2005): Microbiologia. (8a edn), Porto Alegre, Artemed: p:894.

[12] Scotter, S.; Aldridge, M. and Capps, K. (2000): Validation of a method for the detection of E. coli $\mathrm{O} 157: \mathrm{H} 7$ in foods. Food Control, 11(2): 85-95.

[13] Allmann, M.; HoÈfelein, C.; KoÈppel, E.; Lüthy, J.; Meyer, R.; Niederhauser, C.; Wegmüller, B. and Candrian, U. (1995): Polymerase chain reaction (PCR) for detection of pathogenic microorganisms in bacteriological monitoring of dairy products. Res Microbiol, 146(1): 85-97.

[14] Seo, K.H.; Brackett, R. E. and Frank, J.F. (1998): Rapid detection of Escherichia coli O157:H7 using immuno-magnetic flow cytometry in ground beef, apple juice, and milk. Int J Food Microbiol, 44(1): 115-123.

[15] Collee, J.G.; Fraser, A.G.; Marmion B.P. and Simmons, A. (1996): Practical Medical Microbiology,14th ed. Churchill, Living Stone, NewYork.

[16] Holth, I.G.; Krieg, N.R.; A.Sneath, P.H.; Staley, I.T.; Williams, S.T. (2000): Bergey's Manuel of Determinative
Bacteriology.9th Edn. Lippincott Williams and Wilkins, Philadelphia. ISBN: 0-683- 00603-7.

[17] Quinn, P.J.; K.Markey, B.; Carter, M.E.; Donnelly, W.J. and Leonard, F.E. (2002): Veterinary Microbiology and Microbial Disease. 1st Edn. Blackwell Publishing Professional, Iowa. pp: 461-464. ISBN: 0- 632-05525-1.

[18] Reischl, U.; Pulza, M.; Ehret, W. and Wolf, H. (1994): PCR based detection of mycobacterium in sputum samples using a simple and reliable DNA extraction protocol. Bio Techniques, 17: 844-845.

[19] Brakstad, O.G.; Aasbakk, K. and Maeland, J.A. (1992): Detection of Staphylococcus aureus by polymerase chain reaction amplification of the nuc gene. J Clin Microbiol, 30(7):1654-1660.

[20] Aranda, K.R.S.; Fagundes-Neto, U. and Scaletsky I.C.A. (2004): Evaluation of multiplex PCRs for diagnosis of infection with diarrheagenic Escherichia coli and Shigella spp. J Clin Microbiol, 42 (12): 5849-5853.

[21] Haggag, Y.N. (2006): Public health importance of some bacterial pathogens isolated from milk and milk products. $\mathbf{J}$ Vet Microbiol Sci, (1).

[22] Zakary, E.M.; Nassif, M.Z. and Mohammed, G.M.O. (2011): Detection of Staphylococcus aureus in bovine milk and its product by real time PCR assay. Global J Biotech and Biochem, 6(4): 171177.

[23] Abo-Shama, U.H. (2014): Prevalence and antimicrobial susceptibility of Staphylococcus aureus isolated from cattle, buffalo, sheep and goats raw milk in Sohag Governorate, Egypt. Assiut Vet Med J, 60 (141): 63-72.

[24] Fagundes, H.; Barchesi, L.; Filho, A.N.; Ferreira, L.M. and Oliveira, C.A.F. (2010): Occurrence of Staphylococcus aureus in raw milk produced in dairy farms in São Paulo State, Brazil. Braz J Microbiol, 41(2): 376-380.

[25] Kumar, R. and Prasad, A. (2010): Detection of E. coli and Staphylococcus 
in milk and milk products in and around Pantnagar. Pakistan J Nutr, 1(3):151-152

[26] FAO. (1998): Microflora of milk. Milk and milk products in human nutrition. FAO Food and Nutrition Paper No. 28 ISBN 92- 5-20534-6. Cataloguing in Publication David Lubin Memorial Library FAO, Rome (Italy)

[27] Kousta, M.; Mataragas, M.; Skandamis, P. and Drosinos, E.H. (2010): Prevalence and sources of cheese contamination with pathogens at farm and processing levels. Food Control, 21(6): 805-815.

[28] Parker, M.T. (1993): The significance of phage typing pattens of Staphylococcus aureus. In: Staphylococcal Infections, Vol. I. Clinical and Epidemiological Aspects. (C.S.F. Easmon and C. Adlan, eds.). Academic Press, pp. 34-61.

[29] FDA. U.S. Food and Drug Administration (2001): Methods for Specific Pathogens: Escherichia coli, Salmonella and Vibrio, 8th edition. FDA Center for Food Safety and Applied Nutrition, Bacteriological Analytical Manual. (Available at www.cfsan.fda.). All amendments up to November 2005. Kuala Lumpur, Malaysia, MDC Publishers Sdn. Bhd. pp. 1-265.

[30] El-Gedawy, A.A.; Ahmed, H.A. and Awadallah M.A.I. (2014): Occurrence and molecular characterization of some zoonotic bacteria in bovine milk, milking equipment and humans in dairy farms, Sharkia, Egypt. Int Food Res J, 21(5): 1813-1823.

[31] Fadel, H.M. and Ismail, J. (2009): Prevalence and significance of Staphylococcus aureus and Enterobacteriaceae species in selected dairy products and handlers. Int $\mathbf{J}$ Dairy Sci, 4(3): 100-108.

[32] Abdel-All, A.A.A., Yasin, B.M.H. and Ibrahim, A.K. (2010): Assessment of conventional and molecular features of Staphylococcus aureus isolated from bovine milk samples and contact dairy workers. Global Veterinaria, 4(2): 168175.
[33] Da Silva, E.; Siqueira, A.; Martins, J.; Ferreira, W. and Da Silva, N. (2004): Identification and in vitro antimicrobial susceptibility of Staphylococcus species isolated from goat mastitis in the Northeast of Brazil. Small Rumin Res, 55(1): 45-49.

[34] Osman, K.M.; Mustafa, A.M.; Elhariri, M. and Abdelhamed, G.S. (2013): Association and combinations and virulence genes encoding serotypes in pathogenic $E$. coli recovered from diarrhoeic calves, sheep and goat. Transbound Emerg Dis, 60(1): 69-78

[35] Al-Zogibi, O.G.; Mohamed, M.I.; Hessain, A.M.; El-Jakee, J.K. and Kabli, S.A. (2015): Molecular and serotyping characterization of shiga toxogenic Escherichia coli associated with food collected from Saudi Arabia. Saudi J Biol Sci, 22(4): 438-442.

[36] Son, I.; Van Kessel, J.A.S. and Karns. J.S. (2009): Genotypic diversity of Escherichia coli in a dairy farm. Foodborne pathog Dis, 6(7): 837-847.

[37] Ombarak, R.A.; Hinenoya, A.; Awasthi, S.P.; Iguchi, A.; Shima, A.; Elbagory, A.R. and Yamasaki, S. (2016): Prevalence and pathogenic potential of Escherichia coli isolates from raw milk and raw milk cheese in Egypt. Int J Food Microbiol, 221: 69-76.

[38] Disassa, N.; Sibhat, B.; Mengistu, S.; Muktar, Y. and Belina, D. (2017): Prevalence and antimicrobial susceptibility pattern of E. coli O157: H7 isolated from traditionally marketed raw cow milk in and around Asosa Town, Western Ethiopia. Veterinary medicine international, 2017:7581531.

[39] Kim, C.H.; Khan, M.A.; Morin, E.; Hurley, W.L.; Tripathy, D.N.; Kehrli, M.J.; Olouch, A.O. and Kakomal, I. (2001): Optimization of the PCR for detection of Staph. aureus nuc gene in bovine milk. J Dairy Sci, 84(1): 74-83.

[40] Rosenstraus, M.; Wang, Z.; Chang, S.H.; De Bonville, D. and Spadoro, J.P. (1998): An internal control for routine diagnostic PCR: design, properties and effect on 
clinical performance. J Clin Microbiol, 36(1): 191-197.

[41] Abri, R.; Razavilar, V.; Javadi, A.; Ahangarzadeh Rezaee, M. and Zahraei Salehi, T. (2017): Evaluation of the prevalence of enterotoxigenic and enteropathogenic Escherichia coli in raw milk and dairy products by Duplex-PCR. J Comp Pathobiol, 14(2): 2157-2164.
[42] El-Jakee, J.; Zaki, E. and Farag, R. (2010): Properties of enterotoxigenic Staph. aureus isolated from mastitic cattle and buffaloes in Egypt. J Am Sci, 11:170178.

[43] Ahmadi, M.; Rohani, S.M.R. and Ayremlou, N. (2010): Detection of Staphylococcus aureus in milk by PCR. Comp Clin Pathol, 19(1):91-94.

$$
\begin{aligned}
& \text { الملخص العربي } \\
& \text { الأهمية المشتركة لبعض أنواع البكتيريا المعزولة من ألبان المجترات الصغيرة وأيادي عمال الحلابة }
\end{aligned}
$$

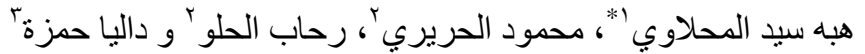

$$
\begin{aligned}
& \text { ' قسم الصحة والأمر اض المشتركة وسلوكيات الحيو ان ور عايته، كلية الطب البيطري، جامعة قناة السويس }
\end{aligned}
$$

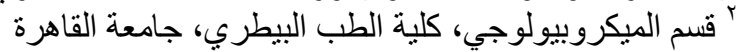

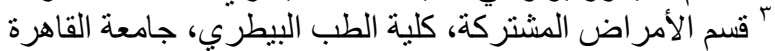

تعد المكورات العنقودية والإيشيريشيا كو لاي ذات الإمر اض المعوي من ميكروبات التسمم الغذائي البكتبرية المشتركة و التي التي

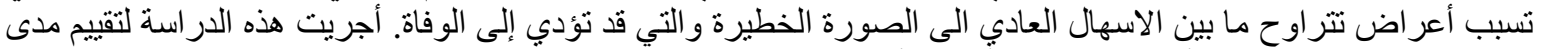

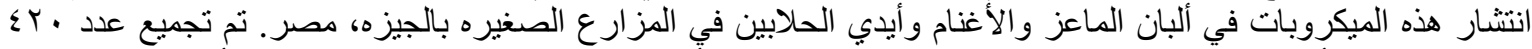

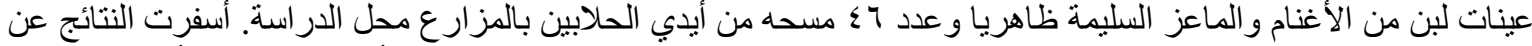

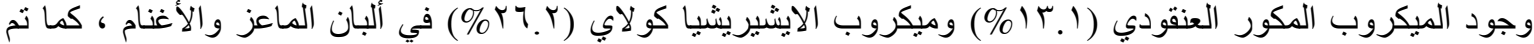

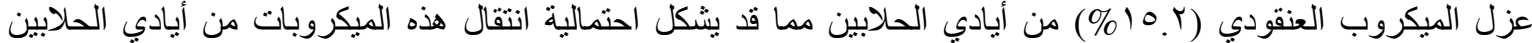

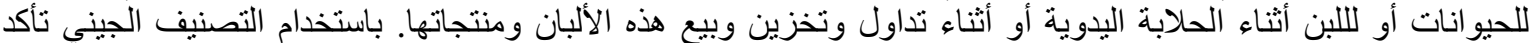

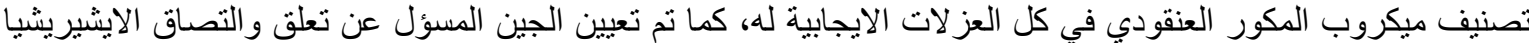

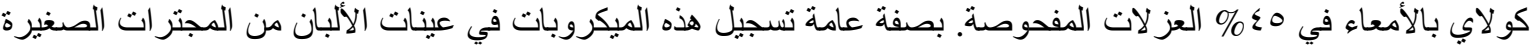

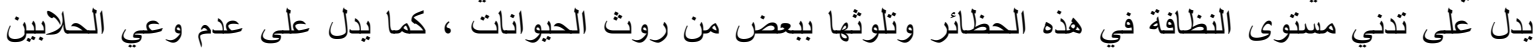
باسترشادات الحلابة الصحية الصحيحة. 